\title{
Beschadigde voeten door Vierdaagse
}

\section{De maand juli staat al jaren in het teken van de befaamde Vierdaagse van Nijmegen. Voor velen betekent dit 4 dagen lang 40 kilometer per dag lopen. Een prestatie op zich! De voeten krijgen tijdens dit sportevenement enorm veel te verduren en raken soms (ern- stig) beschadigd. Zo ook bij Jennifer, die voor het eerst de Vierdaagse heeft gelopen.}

Tekst Toos Mennen, medisch pedicure

J ennifer, 33 jaar, vraagt mij in mei om advies hoe ze het best haar voeten kan verzorgen en behandelen, want ze is aan het trainen voor de Vierdaagse. Haar voeten vertonen dan al fikse blaren. Ik vraag haar of ze haar wandelschoenen mee wil brengen en wat schetst mijn verbazing: het zijn kunststof sneakers zonder binnenvoering met aan de binnenzijde overal naden en onregelmatigheden. De wandelsokken zijn enkelsokjes van 13 in een dozijn met naden. Jennifer verweert zich met de mededeling dat ze hier toch echt het lekkerst op loopt en dat ze deze schoenen ook echt goed heeft ingelopen. Wandelaars die de Vierdaagse nog nooit gelopen hebben, bereiden zich over het algemeen voor met een op maat gemaakt schema, waarbij de afstand steeds wat langer wordt. Er worden veel en diverse adviezen gegeven, maar over het algemeen zijn de deskundigen op wandelgebied het erover eens dat goed passende wandelschoenen een must zijn. Liefst van ademend materiaal en een binnenvoering zonder naden of stiksels. Wandelsokken hebben een goede schokdemping in het voorvoet- en hielgedeelte, nemen goed vocht op en hebben geen naden. Verder kan een weke voethuid met wat kamferspiritus worden behandeld en kun je de voet preventief tapen om blaren zoveel mogelijk te voorkomen.

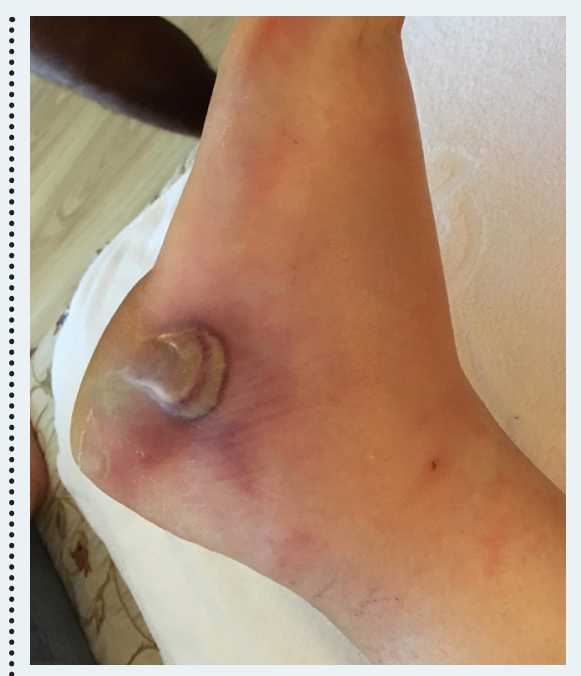

De huid van mensen verschilt nogal. Waar de ene mens snel eelt heeft, zal een ander een weke huid hebben of snel blaren krijgen. De voetstand en afwikkeling van de voet zijn ook bepalend voor een probleemloos looppatroon. Gebleken is dat na 15 $\mathrm{km}$ wandelen de gemiddelde voet niet meer 100 procent correct afwikkelt. Conclusie: er wordt gecompenseerd, waardoor zich vaak al de eerste problemen voordoen.

Zo ook bij Jennifer, waarbij goede raad echter duur was. Letterlijk en figuurlijk, want ze heeft simpelweg niet het geld om goede sokken en schoenen aan te schaffen. Dus loopt ze de Vierdaagse op haar sneakers en als ze de moed verliest, wordt ze altijd wel opgezweept door muziek, live-bandjes, disc-jockeys, applaudise-

'Enorme blaren, bloedblaren, vocht, dikke enkels en scheuren in de voethuid' rende mensen langs de kant en niet in de laatste plaats door een grote dosis doorzettingsvermogen. Resulterend in enorme blaren, bloedblaren, vochtophopingen, dikke enkels en scheuren in haar voethuid. De open blaren zorgden voor een infectie, waarvoor ik haar heb doorverwezen naar haar huisarts, die de losse delen van haar voetzolen en zijkanten heeft verwijderd, alles heeft schoongespoeld en haar een antibioticakuur heeft voorgeschreven. Ze is hier nu nog herstellend van.

Voor Jennifer waarschijnlijk geen tweede keer meer, maar met de juiste schoenen en sokken zou het vast beter gelukt zijn. 